\title{
Paradoxical Expression of Adenosine Deaminase in T Cells Cultured from a Patient with Adenosine Deaminase Deficiency and Combined Immunodeficiency
}

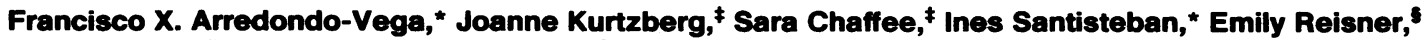 \\ M. Sue Povey," and Michael S. Hershfield"" \\ Departments of *Medicine, 'Biochemistry, ${ }^{\ddagger}$ Pediatrics, and ${ }^{\S}$ Pathology, Duke University Medical Center, Durham, \\ North Carolina 27710; and "The Medical Research Council Human Biochemical Genetics Unit, \\ University College London, London NW1 2HE, United Kingdom
}

\begin{abstract}
T lymphocytes cultured from a patient (T.D.) with adenosine deaminase (ADA) deficiency expressed ADA activity in the normal range, inconsistent with her severe immunodeficiency, metabolic abnormalities, and with the absence of ADA activity in her B lymphocytes and other nucleated hematopoietic cells. ADA from T.D. $T$ cells had normal $K_{m}$, heat stability, and sensitivity to ADA inhibitors. Examination of HLA phenotype and polymorphic DNA loci indicated that T.D. was neither chimeric nor a genetic mosaic. Amplified and subcloned ADA cDNA from $\mathrm{ADA}^{+}$T.D. $T$ cells was shown by allele-specific oligonucleotide hybridization to possess the same mutations $\left(\operatorname{Arg}_{101} \rightarrow\right.$ Trp, $\operatorname{Arg}_{211} \rightarrow$ His) previously found in the $\mathbf{A D A}^{-}$ T.D. B cell line GM 2606 (Akeson, A. L., D. A. Wiginton, M. R. Dusing, J. C. States, and J. J. Hutton. 1988. J. Biol. Chem. 263:16291-16296). Our findings suggest that one of these mutant alleles can be expressed selectively in IL-2-dependent $T$ cells as stable, active enzyme. Cultured $T$ cells from other patients with the $\mathbf{A r g}_{211} \rightarrow$ His mutation did not express significant ADA activity, while some $B$ cell lines from a patient with an Arg $_{101} \rightarrow$ Gln mutation have been found to express normal ADA activity. We speculate that $\mathrm{Arg}_{101}$ may be at a site that determines degradation of ADA by a protease that is under negative control by IL-2 in T cells, and is variably expressed in B cells. IL-2 might increase ADA expression in T cells of patients who possess mutations of $\mathrm{Arg}_{101}$. (J. Clin. Invest. 1990. 86:444-452.) Key words: mutation - mRNA • enzyme $\bullet$ purine $\bullet$ heterogeneity
\end{abstract}

\section{Introduction}

The majority of individuals with inherited deficiency of adenosine deaminase (ADA), ${ }^{1}$ probably over 200 since the first report (1), have cellular immune dysfunction, usually with the

Address correspondence and reprint requests to Dr. Michael S. Hershfield, Box 3049, Duke University Medical Center, Durham, NC 27710.

Received for publication 18 January 1990 and in revised form 10 April 1990.

1. Abbreviations used in this paper: ADA, adenosine deaminase; ASO, allele-specific oligonucleotide; $\mathrm{PCR}$, polymerase chain reaction; PEGADA, polyethylene glycol modified ADA; PNP, purine nucleotide phosphorylase; SCID, syndrome of combined immunodeficiency.

J. Clin. Invest.

(C) The American Society for Clinical Investigation, Inc. 0021-9738/90/08/444/09 \$2.00

Volume 86, August 1990, 444-452 syndrome of combined immunodeficiency (SCID) $(2,3)$. About 10 healthy individuals, identified through screening, have had normal immune function (4-12). Both groups lack ADA activity in erythrocytes, but whereas the former also has $\leq 1 \%$ of normal activity in blood mononuclear cells and B cell lines (complete deficiency) $(6,9,10,13)$, the latter has $4-70 \%$ of normal activity (partial deficiency). Structural gene mutations, which presumably diminish enzyme stability or catalytic activity to different extents, occur in both groups (14-21). The degree of ADA deficiency determines the severity of toxic effects of deoxyadenosine, including dATP pool expansion and inactivation of $S$-adenosylhomocysteine hydrolase. Profound $T$ cell depletion, the hallmark of complete ADA deficiency, has been attributed to sensitivity of this lineage to dATP accumulation (reviewed in reference 3 ). The fact that relatively little residual ADA activity prevents metabolic disturbances and preserves cellular immunity in partial deficiency has encouraged development of methods for treating immunodeficient patients by enzyme replacement or by inserting a functional ADA gene into stem cell progenitors of $T$ cells.

In the context of present understanding of the molecular and clinical heterogeneity of ADA deficiency, we report an unexpected observation: the expression of high levels of ADA activity in cultured $T$ cells of a patient with SCID, whose other hematopoietic cells express levels typical of complete enzyme deficiency.

\section{Methods}

Materials. Erythro-9-(2-hydroxy-3-nonyl)adenine (EHNA) was obtained from Burroughs Wellcome Co. (Research Triangle Park, NC), $\left[8-{ }^{14} \mathrm{C}\right]$ adenosine and $\left[8-{ }^{14} \mathrm{C}\right]$ inosine from Moravek Biochemicals (Brea, CA), and restriction endonucleases from Boehringer Mannheim Biochemicals (Indianapolis, IN) or Pharmacia Fine Chemicals, Piscataway, NJ. Rabbit antiserum to calf ADA was kindly provided by $P$. Daddona (Centocor, Inc., Malvern, PA). The B cell lines GM 2606 and GM 2608 were obtained from the Human Genetic Mutant Cell Repository (Camden, NJ) (GM 2606 is incorrectly listed as a male cell line in the Repository catalogue).

Cell isolation and culture. Nucleated cells isolated from heparinized blood or bone marrow by density gradient centrifugation were seeded at $0.5-1 \times 10^{6} / \mathrm{ml}$ in RPMI 1640 medium and $10 \%$ heat-inactivated $\left(30 \mathrm{~min}, 56^{\circ} \mathrm{C}\right)$ fetal calf serum under $5 \% \mathrm{CO}_{2}$ at $37^{\circ} \mathrm{C}$. For initiating $\mathrm{T}$ cell cultures, medium was supplemented with 5 or $10 \% \mathrm{~T}$ cell-conditioned medium (22) and $8 \mathrm{U} / \mathrm{ml}$ human recombinant IL-2 (IL-2r; DuPont, Boston, MA). T cells were cloned by limiting dilution in this medium plus $10 \%$ horse serum (Gibco Laboratories, Grand Island, NY) without feeder cells, or over irradiated feeder cells by a procedure similar to Hakoda et al. (23), as follows. On day 6 of culture committed $\mathrm{T}$ cells $\left(\mathrm{CD}^{+}\right)$were quantified by surface antigen analysis; after dilution in medium, 100- $\mu$ aliquots containing $1,000,100,10$, and $1 \mathrm{~T}$ cells were distributed into flat-bottom microtiter plates containing per well $2 \times 10^{4}$ irradiated (2,500 rad), opposite sex feeder cells 
( $10^{4}$ each of normal blood mononuclear cells from 3-d cultures with either 1\% PHA [Burroughs Wellcome Co.] or $10 \mu \mathrm{g} / \mathrm{ml}$ Con A [Sigma Chemical Co., St. Louis, MO]). Clones were expanded without feeder cells and maintained at $2-12 \times 10^{5} / \mathrm{ml}$. EBV-transformed B cell lines were established in medium supplemented with supernatant from the B95.8 cell line and cloned by limiting dilution without feeder cells.

Enzyme assays. Nucleated cells $\left(0.2-2 \times 10^{6}\right)$ were lysed by three cycles of freezing and thawing in $0.15 \mathrm{ml}$ of $10 \mathrm{mM}$ Tris- $\mathrm{HCl}, \mathrm{pH} 7.4$, and $1 \mathrm{mM}$ EDTA. After centrifugation for $2 \mathrm{~min}$ in a microcentrifuge, $0.1 \mathrm{ml}$ of supernatant was passed over Sephadex G-25 equilibrated with $25 \mathrm{mM}$ Tris- $\mathrm{HCl}, \mathrm{pH} 7.4,15 \mathrm{mM} \mathrm{KCl}, 1 \mathrm{mM}$ EDTA, and $1 \mathrm{mM}$ dithiothreitol using the "spun-column" technique (24). ADA activity was assayed (25) using $150 \mu \mathrm{M}\left[{ }^{14} \mathrm{C}\right]$ adenosine $(20,000-30,000 \mathrm{cpm} /$ nmol) and purine nucleoside phosphorylase (PNP) (26) using $100 \mu \mathrm{M}$ $\left[{ }^{14} \mathrm{C}\right]$ inosine $(20,000-30,000 \mathrm{cpm} / \mathrm{nmol})$. After incubation at $37^{\circ} \mathrm{C}, 5$ $\mu \mathrm{l}$ of $50-\mu \mathrm{l}$ reactions were spotted with unlabeled ultraviolet (UV) markers on cellulose thin layer plates (PolygramCel $400 \mathrm{UV}_{250}$; Macherey-Nagel, Düren, FRG), which were developed in $1 \%$ Tris base (ADA) or water (PNP). ADA in cell extracts was analyzed by electrophoresis on cellulose acetate strips (Helena Laboratories, Beaumont, TX) in $0.1 \mathrm{M}$ sodium phosphate, $\mathrm{pH}$ 6.5; in situ staining for ADA was modified from the method of Spencer et al. (27). Protein was determined (28) using BSA as standard.

Surface antigen and HLA phenotyping. Expression of cell surface antigens was analyzed by indirect immunofluorescence and FACS of 10,000 cells on an EPICS 753 flow cytometer (Coulter Electronics Inc., Hialeah, FL) $(29,30)$. Sorting of $\mathrm{T}$ cells into $\mathrm{CD}^{+}$and $\mathrm{CD} 8^{+}$populations was performed as described (31). Monoclonal antibodies were obtained from Becton Dickinson Monoclonal Center (Mountain View, CA), Ortho Diagnostic Systems Inc. (Westwood, MA), and Coulter Immunology (Hialeah, FL). HLA-ABC testing was performed by two stage lymphocytotoxicity (32) using trypan blue dye exclusion. HLA-DR testing was done with reagents from Biotest (Denville, $N J$ ) or Pel-Freeze Biologicals (Rogers, AR).

Allele-specific oligonucleotide analysis of amplified ADA cDNA. Polymerase chain reaction (PCR) was used to amplify basepairs 219-846 of the ADA cDNA (numbering as in references 17 and 18) (33). Two 33-mer oligonucleotides, dCAAGCTTGGAGAGGGATCGCCCTCCCAGCTAAC and dGGAATTCGAAGTGCATGTTTTCCTGCCGCAGCC, were used as primers; italicized nucleotides were added to generate $5^{\prime}$ Hind III and $3^{\prime}$ Eco RI sites in the 693-bp product. The amplified cDNA was probed with two pairs of 18-mer allele-specific oligonucleotide (ASO), dTGGAGGTG(C/T)GGTACAGTC corresponding to ADA cDNA basepairs 388-405 (exon 4), and dGCATTCACC(G/A)TACTGTCC to basepairs 718-735 (exon 7). The first pair contained either $C$ or $T$ at position 9 (cDNA basepair 396) and the second either $G$ or $A$ at position 10 (cDNA basepair 727), representing, respectively, the concensus wildtype ADA sequence and mutant ADA alleles identified in cDNA from the GM 2606 lymphoblastoid cell line (18).

$5 \mu \mathrm{g}$ poly $\mathrm{A}^{+}$mRNA (34) was used to prepare first strand cDNA using a cDNA synthesis kit (Pharmacia Fine Chemicals). After phenol-chloroform extraction and ethanol precipitation, the RNA/ DNA product was resuspended in $10 \mu \mathrm{l}$ of $10 \mathrm{mM}$ Tris- $\mathrm{HCl}$ and $1 \mathrm{mM}$ EDTA, pH 7.5, and mixed with $1 \mu \mathrm{mol}$ of each PCR primer, PCR buffer, a mixture of $4 \mathrm{dNTPs}$, and $2.5 \mathrm{U}$ of Taq polymerase in a total volume of $100 \mu \mathrm{l}$ (GeneAmp kit; Perkin Elmer-Cetus, Norwalk, CT). Amplification was achieved by carrying out 30 reaction cycles $(2 \mathrm{~min}$ at $94^{\circ} \mathrm{C} ; 3 \mathrm{~min}$ at $55^{\circ} \mathrm{C} ; 2 \mathrm{~min}$ at $72^{\circ} \mathrm{C}$ ), followed by a single cycle in which time at $72^{\circ} \mathrm{C}$ was $10 \mathrm{~min}$, using a thermal cycler (Ericomp, San Diego, CA). To confirm amplification, $5 \mu \mathrm{l}$ of PCR reactions were electrophoresed in $0.8 \%$ agarose gels, transferred to nitrocellulose, and hybridized with a ${ }^{32} \mathrm{P}$-end labeled oligonucleotide probe for ADA cDNA bases 360-386. The amplified target from the rest of the reaction was isolated from a second gel and used directly for ASO analysis (see below), or was subcloned into Eco RI/Hind III sites of pUC18. Plasmid DNA was prepared from random recombinant clones and subjected to a second round of PCR as above before ASO analysis.
For ASO analysis, uncloned, amplified DNA was denatured with $1.5 \mathrm{M} \mathrm{NaOH}$ for $5 \mathrm{~min}$ at $65^{\circ} \mathrm{C}$, neutralized with $1 \mathrm{M}$ final concentration of ammonium acetate, $\mathrm{pH} 7.0$, and aliquots were applied to a Gene Screen Plus membrane (DuPont) using a Minifold II slot blot apparatus (Schleicher \& Schuell, Inc., Keene, NH). After prehybridization with $150 \mu \mathrm{l} / \mathrm{cm}^{2}$ of $5 \times \mathrm{SSC}, 20 \mathrm{mM} \mathrm{NaH}_{2} \mathrm{PO}_{4}, \mathrm{pH} 7.0,7 \%$ SDS and $10 \times$ Denhardt's solution containing $100 \mu \mathrm{g} / \mathrm{ml}$ denatured salmon sperm DNA, membranes were hybridized for $16 \mathrm{~h}$ at $47^{\circ} \mathrm{C}$ for the exon 4 and at $45^{\circ} \mathrm{C}$ for the exon 7 ASO with the same solution containing $1.5 \times 10^{7} \mathrm{cpm} / \mathrm{ml}$ of ASO that had been $5^{\prime}$ end labeled with $\left.{ }^{32} \mathrm{P}\right] \mathrm{ATP}$ (3,000 Ci/mmol). Hybridization conditions were determined as previously described $(35,36)$. Membranes were washed in $2 \times$ SSC and $0.1 \%$ SDS for $15 \mathrm{~min}$ at $45^{\circ} \mathrm{C}$ for both mutant ASO, and for $20 \mathrm{~min}$ at $45^{\circ} \mathrm{C}$ for both wild-type ASO. Washed membranes were exposed to $\mathrm{x}$-ray film (X-omat RP; Eastman Kodak Co., Rochester, NY) between intensifying screens for $5-16 \mathrm{~h}$ at $-70^{\circ} \mathrm{C}$. Aliquots of cloned and reamplified DNA (one-tenth of PCR reaction mixtures) were electrophoresed in quadruplicate $0.8 \%$ agarose gels and transferred to ZetaProbe membranes (Bio-Rad Laboratories, Richmond, CA). Each membrane was probed with one of the four ASO as described above.

Northern analysis. Total cellular RNA $(35 \mu \mathrm{g})$ from T and B cells (34) was electrophoresed in a $1 \%$ agarose-37\% formaldehyde gel, transferred to a Hybond-N membrane (Amersham Corp., Arlington Height, IL), and prehybridized in a solution containing $50 \%$ formamide, $5 \times$ Denhardt's solution, $0.1 \%$ SDS, $5 \times$ SSC, and $150 \mu \mathrm{g} / \mathrm{ml}$ denatured salmon sperm DNA at $42^{\circ} \mathrm{C}$. Hybridization was carried out overnight at $42^{\circ} \mathrm{C}$ with $10^{7} \mathrm{cpm}{ }^{32} \mathrm{P}$-labeled, heat-denatured DNA probes in prehybridization solution. The membrane was then washed to a stringency of $0.1 \times \mathrm{SSC}, 0.1 \% \mathrm{SDS}$ at $65^{\circ} \mathrm{C}$. Probe for ADA mRNA was prepared from pADA211 (37), provided by J. Hutton, University of Cincinnati; probe for $S$-adenosylhomocysteine hydrolase was prepared from pDEC16-1 (38).

Genomic DNA analysis. Genomic DNA from cultured lymphoid cells was digested with Hinf I or Alu I, electrophoresed into $0.8 \%$ agarose gels, and transferred to Nytran filters (Schleicher \& Schuell, Inc.). Locus-specific minisatellite probes (20 ng each) p $\lambda \mathrm{g} 3, \lambda M S 31$, and $\lambda$ MS32 (39), kindly provided by Dr. Alec Jeffreys (University of Leicester, Leicester, UK) and ICI Diagnostics (Macclesfield, Cheshire, $\mathrm{UK}$ ), were radiolabeled with $\left[\alpha-{ }^{32} \mathrm{P}\right] \mathrm{dCTP}$ by random priming (Amersham Corp.). The filter was prehybridized at $65^{\circ} \mathrm{C}$ in $1 \mathrm{M} \mathrm{NaCl}, 1 \%$ SDS, and $10 \%$ dextran sulfate, then hybridized in this mixture containing labeled probe and $20 \mu \mathrm{g} / \mathrm{ml}$ of sonicated herring sperm DNA. Filters were washed to a stringency of $0.1 \times \mathrm{SSC}, 0.1 \% \mathrm{SDS}$ at $65^{\circ} \mathrm{C}$, and exposed to $x$-ray film at $-70^{\circ} \mathrm{C}$.

Patient. T.D. developed SCID before age $3 \mathrm{mo}$ and was found to be ADA deficient; her erythrocyte dATP was $1,100 \mathrm{nmol} / \mathrm{ml}$ packed cells vs. $<20 \mathrm{nmol} / \mathrm{ml}$ in healthy patients with partial ADA deficiency (40). A B cell line from T.D., GM 2606, had $<0.5 \%$ of normal ADA activity (6). T.D. received five thymic epithelium transplants before $2 \mathrm{yr}$, and monthly transfusions of irradiated red cells until $9 \mathrm{yr}$. She remained profoundly lymphopenic with minimal immune function; recurrent respiratory infections resulted in chronic pulmonary insufficiency. Lymphocyte function improved with initiation of replacement therapy with polyethylene glycol-modified ADA (PEG-ADA) at age 9 yr (41). Investigation of T.D.'s response to PEG-ADA led to the observations reported below.

\section{Results}

ADA expression by IL-2-dependent $T$ cells. Beginning in August 1986, T cells were cultured from serial samples of blood and bone marrow from T.D. ADA activity and surface marker phenotype of uncultured nucleated cells and $T$ cells derived from them are shown in Tables I and II. Pretreatment marrow $(8 / 86)$ contained myeloid, platelet, and erythroid precursors, but very few lymphocytes; nucleated cells lacked $\mathrm{T}$ cell surface antigens and had $<0.3 \%$ of normal ADA activity. After cul- 
Table I. ADA Activity of Uncultured Mononuclear Cells and IL-2-dependent T Cells from T. D. and Normal Individuals

\begin{tabular}{|c|c|c|c|}
\hline \multirow[b]{2}{*}{ Date } & \multirow[b]{2}{*}{ Source } & \multicolumn{2}{|c|}{ ADA activity (nmol/h per mg) } \\
\hline & & Uncultured nucleated cells & IL-2-dependent $T$ cells \\
\hline \multicolumn{4}{|c|}{ T. D. derived } \\
\hline $8 / 86$ & Marrow & 2.4 & $1,391.0 \quad(\mathrm{~d} 30)^{*}$ \\
\hline $9 / 86$ & Blood & 54.4 & $786.2 \quad(d 46)$ \\
\hline $12 / 86$ & Blood & 51.0 & $253.9 \quad(\mathrm{~d} 29)$ \\
\hline $5 / 87$ & Marrow & 64.0 & $601.3(\mathrm{~d} 16)$ \\
\hline \multirow[t]{3}{*}{$1 / 88$} & Blood & 22.3 & $1,260.0 \quad(\mathrm{~d} 31)$ \\
\hline & & & $321.2(\mathrm{~d} 63)$ sorted, $\mathrm{CD}^{+} 8^{-}$ \\
\hline & & & $3,553.6$ (d63) sorted, $\mathrm{CD}^{-} 8^{+}$ \\
\hline $4 / 88$ & Blood & 52.3 & $689.5(\mathrm{~d} 18)$ \\
\hline \multirow[t]{5}{*}{$8 / 88$} & Blood & & 710.0 (d37) clone $1 \mathrm{~F} 12$ \\
\hline & & & $2,635.4$ (d57) clone $1 \mathrm{~F} 12$ \\
\hline & & & $1,942.8 \quad(\mathrm{~d} 37)$ clone $1 \mathrm{H} 3$ \\
\hline & & & 717.1 (d57) clone $1 \mathrm{C} 8$ \\
\hline & & & 24.1 (d78) clone 4F11 \\
\hline \multirow[t]{2}{*}{ Controls } & Blood & $1,197 \pm 516(n=6)^{\ddagger}$ & $2,047.3 \pm 1,360 \quad(n=7)$ \\
\hline & Marrow & $854 \pm 288(n=7)$ & $1,942.3 \pm 778 \quad(n=5)$ \\
\hline
\end{tabular}

* Days in culture; for controls, time length of culture was $14-105 \mathrm{~d} .{ }^{\ddagger}$ Mean \pm SD.

ture in IL-2-containing medium, $>90 \%$ of the resulting population expressed $\mathrm{T}$ cell surface markers, reflecting the proliferation of rare $\mathrm{T}$ cells or $\mathrm{T}$ cell progenitors. Remarkably, these $\mathrm{T}$ cells had normal ADA activity, 1,391 nmol/h per mg (PNP activity was similar in the uncultured nucleated cells and IL-2-dependent T cells, 2.28 and $2.83 \mu \mathrm{mol} / \mathrm{h}$ per $\mathrm{mg}$, respectively). In subsequent samples from T.D. (Table I, lines 2-8) ADA activity of uncultured mononuclear cells was 22-64 $\mathrm{nmol} / \mathrm{h}$ per $\mathrm{mg}$, vs. $264-3,554 \mathrm{nmol} / \mathrm{h}$ per $\mathrm{mg}$ in $\mathrm{T}$ cells derived from them. The former level is comparable to the $136 \pm 66 \mathrm{nmol} / \mathrm{h}$ per $\mathrm{mg}$ reported for blood mononuclear cells from seven ADA-deficient SCID patients (6), while the latter overlaps the range in mononuclear cells and $\mathrm{T}$ cells from normal individuals (Table I).

Variation in ADA activity among T.D. T cell isolates was reflected in serial changes in activity during $3+$ mo of culture of $T$ cells from a T.D. blood sample (Fig. 1). From the level in uncultured mononuclear cells ADA activity increased $\sim 60$ fold to $1,260 \mathrm{nmol} / \mathrm{h}$ per $\mathrm{mg}$ on day 31 of culture, then fell to 550 on day 45 and to 130 on day 98 . In contrast, PNP activity increased approximately twofold by day 31 , then was stable (data not shown). This range and pattern of ADA expression distinguish cultured T.D. T cells from those of normal individuals and five other ADA-deficient SCID patients who are being treated with PEG-ADA (Fig. 1; Tables I and III). Among the latter, L.B. engrafted transiently after marrow transplantation $(41,42)$, and D.D., like T.D., received transplants of thymic epithelium and several years of monthly red cell transfusions (43).

ADA activity in $46 \mathrm{~T}$ cell clones isolated without use of feeder cells from the $9 / 86$ T.D. blood sample was $232 \pm 144$ $\mathrm{nmol} / \mathrm{h}$ per $\mathrm{mg}$ (range $68-754$ ), and was $318.3 \pm 162 \mathrm{nmol} / \mathrm{h}$ per $\mathrm{mg}$ (range 131-472) in five clones isolated from the $5 / 87$ marrow sample. $T$ cells were cloned from an $8 / 88$ blood sam-

Table II. Surface Antigen Phenotype of Uncultured Nucleated Cells and IL-2-dependent T Cells from Patient T.D.

\begin{tabular}{|c|c|c|c|c|c|c|c|c|}
\hline \multirow[b]{2}{*}{ Date } & \multirow[b]{2}{*}{ Source } & \multirow[b]{2}{*}{ Day in culture } & \multicolumn{6}{|c|}{ Surface antigen expression (percent of cells positive) ${ }^{*}$} \\
\hline & & & $\mathrm{CDI}$ & $\mathrm{CD} 2$ & $\mathrm{CD} 3$ & CD4 & CD8 & DR \\
\hline \multirow[t]{2}{*}{$8 / 86$} & Marrow & 0 & 0 & 0 & 0 & 0 & 0 & 50 \\
\hline & & 30 & 0 & 87 & 90 & 16 & 85 & 55 \\
\hline \multirow[t]{2}{*}{$5 / 87$} & Marrow & 0 & 0 & 7 & 7 & 21 & 9 & 31 \\
\hline & & 16 & 0 & 91 & 91 & 14 & 84 & 82 \\
\hline \multirow[t]{2}{*}{$1 / 88$} & Blood & 24 & 1 & 88 & 82 & 35 & 53 & 82 \\
\hline & & 38 & 0 & 87 & 80 & 18 & 68 & 75 \\
\hline $4 / 88$ & Blood & 18 & 1 & 90 & 88 & 5 & 81 & 63 \\
\hline \multirow[t]{2}{*}{$8 / 88$} & Blood & 37 clone $1 \mathrm{~F} 12$ & 0 & 80 & 75 & 83 & 0 & 85 \\
\hline & & 37 clone $1 \mathrm{C} 8$ & 0 & 86 & 89 & 92 & 6 & 85 \\
\hline
\end{tabular}

* Data were determined by cell sorter analysis as described in Methods. The T cell phenotype of other cultured IL-2-dependent cells described in this paper was also confirmed in this manner or qualitatively by indirect immunofluorescence microscopy. 


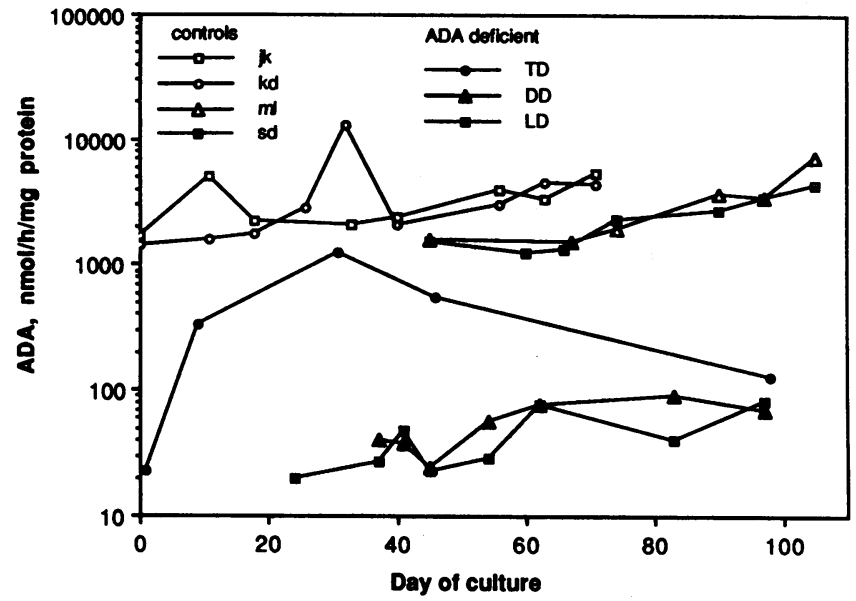

Figure 1. ADA activity of IL-2-dependent T cells during culture. T cells were cultured from mononuclear cells isolated from the $1 / 88$ T.D. peripheral blood sample (Table I), from nucleated blood and marrow cells of four normal individuals, and from blood mononuclear cells of D.D. and L.D., brothers with ADA deficiency and SCID.

ple (Table I) using irradiated feeder cells, which improves $T$ cell cloning efficiency and growth (23). ADA activity in three clones examined after 5-8 wk of culture was $1,765 \pm 971$ $\mathrm{nmol} / \mathrm{h}$ per mg (range 717-2,635), but only $24.1 \mathrm{nmol} / \mathrm{h}$ per $\mathrm{mg}$ in a fourth clone (PNP in the four clones ranged from 2.5-5.5 $\mu \mathrm{mol} / \mathrm{h}$ per $\mathrm{mg}$ ). The level of ADA activity in T.D. T cells was unrelated to surface antigen phenotype (Tables I and II). For example, values of 710 and $2,635 \mathrm{nmol} / \mathrm{h}$ per $\mathrm{mg}$ were found when the $\mathrm{CD} 4^{+} 8^{-}$clone $1 \mathrm{~F} 12$ was sampled on days 37 and 57 of culture. Levels of 321 and $3,554 \mathrm{nmol} / \mathrm{h}$ per $\mathrm{mg}$, respectively, were found in uncloned $\mathrm{CD}^{+} 8^{-}$and $\mathrm{CD} 4^{-} 8^{+}$ cells, which were isolated as $>95 \%$ pure populations by fluorescence-activated sorting of a mass culture.

ADA activity in T.D. B cell lines and other T.D. hematopoietic cells. ADA activity ranged from 0.8 to $8.0 \mathrm{nmol} / \mathrm{h}$ per $\mathrm{mg}$ in extracts of the GM 2606 B cell line, established when T.D.

Table III. ADA Activity in T Cells of Other ADA-Deficient, Immunodeficient Patients

\begin{tabular}{lc}
\hline Patient & ADA activity* \\
\hline & nmol/h per mg protein \\
L.B. & $20.5 \pm 11.2^{\ddagger}$ \\
& $(5.4-47.4)$ \\
C.C. & 7.1 \\
A.De S. & $18.4,30.2$ \\
D.D. & $56.6 \pm 23.8^{\| \prime}$ \\
& $(24.5-91.9)$ \\
L.D. & $42.9 \pm 24.1^{\| 1}$ \\
& $(19.8-81.5)$
\end{tabular}

* Mean \pm SD (range). ${ }^{\ddagger}$ Data are from $14 \mathrm{~T}$ cell clones derived from blood and a marrow sample from L.B. ${ }^{8}$ Data are from reference 57. " Data are from eight (D.D.) or nine (L.D.) samples of uncloned T cells cultured from single blood mononuclear cell preparations over a 3-mo period. was an infant, in a B cell line established a few months before she started PEG-ADA therapy, and in 10 independent B cell clones isolated from her $5 / 87$ marrow sample. This is $<0.2 \%$ of ADA activity in $B$ cell lines from 13 normal individuals (42). PNP activity in $\mathrm{ADA}^{-} \mathrm{B}$ cell clones and $\mathrm{ADA}^{+} \mathrm{T}$ cell clones from the marrow sample were similar, $1.70 \pm 0.9$ and $2.01 \pm 1.8 \mu \mathrm{mol} / \mathrm{h}$ per $\mathrm{mg}$, respectively. The ADA activity in extracts of cultured T.D. T cells was easily demonstrated by in situ staining after electrophoresis on cellulose acetate, while T.D. B cell lines showed no staining (Fig. 2). Freshly isolated blood granulocytes and B cells from T.D. were also ADA deficient, with 2.2 and $10.2 \mathrm{nmol} / \mathrm{h}$ per $\mathrm{mg}$, respectively. We tried to isolate $\mathrm{T}$ cells from a blood sample by rosetting with sheep erythrocytes, but the cells obtained were mostly monocytes and had very low ADA activity, $0.9 \mathrm{nmol} / \mathrm{h}$ per $\mathrm{mg}$.

Characteristics of $A D A$ activity in $A D A$-expressing T.D. $T$ cells. Residual adenosine deaminating activity in blood mononuclear cells of patients with complete ADA deficiency reflects a minor adenosine aminohydrolase $(6,44,45)$. However, the activity in extracts of cultured $T$ cells and $T$ cell clones from T.D. showed several characteristics of authentic ADA, including the same electrophoretic mobility (Fig. 2); a $K_{\mathrm{m}}$ for Ado of $35 \mu \mathrm{M}$ (Fig. $3 \mathrm{~A}$ ), comparable to $25-50 \mu \mathrm{M}$ for purified human ADA, vs. $2-3 \mathrm{mM}$ for the aminohydrolase $(44,45)$; and a similar rate of heat inactivation as ADA in extracts of control human $\mathrm{T}$ and $\mathrm{B}$ cell lines (Fig. $3 \mathrm{~B}$ ). The ADA activity in extracts of T.D. T cells was also inhibited $>98 \%$ by $5 \mu \mathrm{M}$ erythro-9-(2-hydroxy-3-nonyl)adenine, a poor inhibitor of the aminohydrolase, and was inhibitable by antiserum to ADA (data not shown).

Source of ADA-expressing $T$ cells. We were concerned that $\mathrm{ADA}^{+} \mathrm{T}$ cells from T.D. might be engrafted cells from donors of the erythrocytes or thymic epithelium she had received (see above). However, both cloned and uncloned T cells from T.D. expressed one allele from each parent at the HLA A and B loci (Table IV). The chance of finding this HLA A and B phenotype in the Caucasian population is $1: 10,000$. For further confirmation, polymorphism in genomic DNA of $\mathrm{ADA}^{-} \mathrm{B}$ and $\mathrm{ADA}^{+} \mathrm{T}$ cells from T.D. was tested with three locus-specific minisatellite probes (39). Results with probes $\lambda$ MS31 and $p \lambda g 3$ are shown (Fig. 4). T.D. was heterozygous at each locus; band patterns from her $T$ and $B$ cells were identical and quite different from an unrelated control. For p $\lambda \mathrm{g} 3$, a parent of the patient was also tested, and was found to share one allele with T.D.-derived T and B cells (Fig. 4 B). Similar results were obtained for $\lambda$ MS32 (not shown). The three probes used are

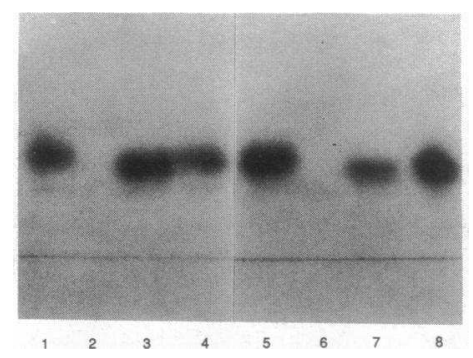

Figure 2. In situ staining for ADA activity after electrophoresis of cell extracts on cellulose acetate. Lanes 1 and 4, Control 1 ( $3.3 \mu \mathrm{g}$ protein); lane 2, T.D. B cell clone 9 (from 5/87 marrow sample; $17.6 \mu \mathrm{g})$; lane 3 , T.D. $\mathrm{T}$ cell clone $1 \mathrm{H} 3$ (from $8 / 88$ blood sample; $5.0 \mu \mathrm{g})$; lanes 5 and 8 , control $2(4.5 \mu \mathrm{g})$; lane 6, T.D. B cell line GM $2606(11.8 \mu \mathrm{g})$; lane 7, T.D. T cell clone 1F12 (from $8 / 88$ blood sample; $1.8 \mu \mathrm{g})$. PNP activity of the samples shown ranged from 1,760 to $5,522 \mathrm{nmol} / \mathrm{h}$ per $\mathrm{mg}$ protein. 

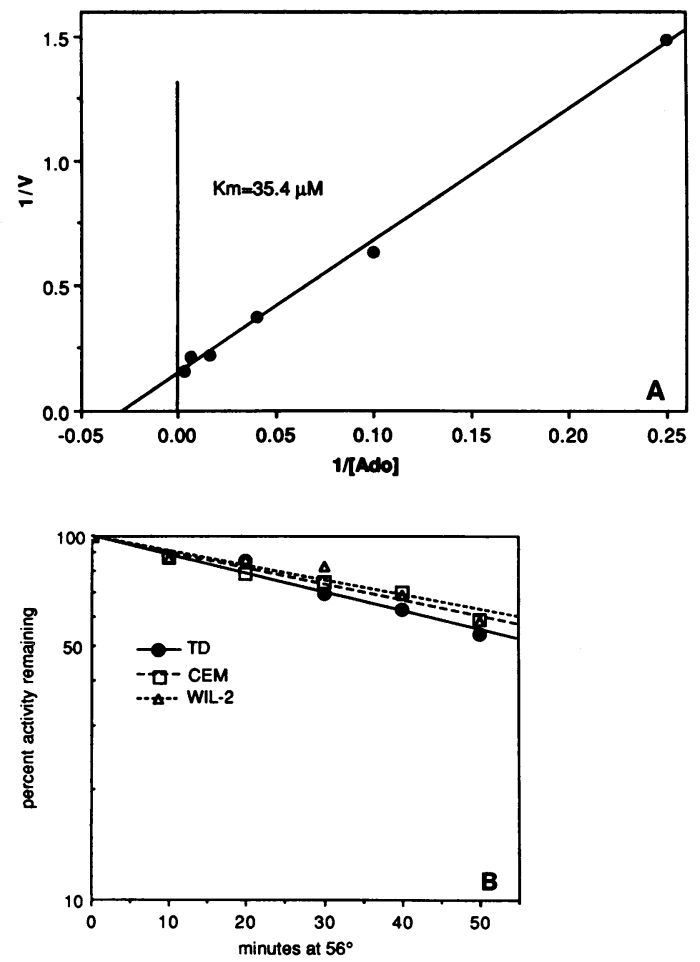

Figure 3. Heat inactivation of ADA activity $(A)$ and $K_{\mathrm{m}}$ for adenosine $(B) . A$, Extracts of T.D. T cells $(1 / 88$ sample, Table $I)$ and of the CEM human T and WI-L2 human B lymphoblastoid cell lines were diluted to $1 \mathrm{mg}$ protein/ml in $25 \mathrm{mM}$ Tris- $\mathrm{HCl}, \mathrm{pH} \mathrm{7.4,15 \textrm {mM }}$ $\mathrm{KCl}, 1 \mathrm{mM}$ EDTA, and $1 \mathrm{mM}$ dithiothreitol, and then incubated in duplicate at $56^{\circ} \mathrm{C}$. At the indicated times aliquots were removed to tubes on ice and then assayed for ADA activity at $37^{\circ} \mathrm{C}$ as in Methods. The ADA activities of the unheated extracts of T.D., CEM, and WI-L2 extracts were $1,120,8,180$, and $1,704 \mathrm{nmol} / \mathrm{h}$ per $\mathrm{mg}$, respectively. $B$, For determining $K_{\mathrm{m}}$, the concentration of [ $\left.{ }^{14} \mathrm{C}\right]$ adenosine was varied from $3 \mu \mathrm{M}$ to $1.05 \mathrm{mM}$ and incubations varied from 5 to $20 \mathrm{~min}$.

highly informative, with heterozygosities $(\mathrm{H})$ of $97-99 \%$; the chance of two unrelated individuals sharing a genotype at each of the three loci is approximately $q^{2}(2-q)$, where $q=1-H$ (39). Thus, the cumulative probability of false association in the present case is $10^{-9}-10^{-10}$.

Analysis of ADA alleles in $T$ cells from T.D. While the present studies were in progress, Akeson et al. (18) identified point mutations in cDNA from the T.D.-derived B cell line GM 2606, $C^{396} \rightarrow T$ (exon 4) changing $A{ }_{101}$ to $\operatorname{Trp}$ in one

Table IV. HLA Phenotype of T Cells from T.D.

\begin{tabular}{lllll}
\hline \multicolumn{1}{c}{ Source } & \multicolumn{1}{c}{ Cell type } & \multicolumn{3}{c}{ HLA phenotype } \\
\hline T.D. 10/86 & Blood mononuclear cells & A 11,28 & B 51,44 & Cw 1 \\
T.D. 8/86 & B.M. T cells & A 11,28 & B 51,44 & Cw 1 \\
T.D. 5/87 & B.M. T cells, 3 clones & A 11,28 & B 51,44 & Cw 1 \\
T.D 1/88 & Blood T cells & A 11,28 & B 51,44 & Cw 1 \\
Mother & Blood mononuclear cells & A 26,11 & B 51,14 & -* \\
Father & Blood mononuclear cells & A 9,28 & B 7,44 & -
\end{tabular}

* Not done.
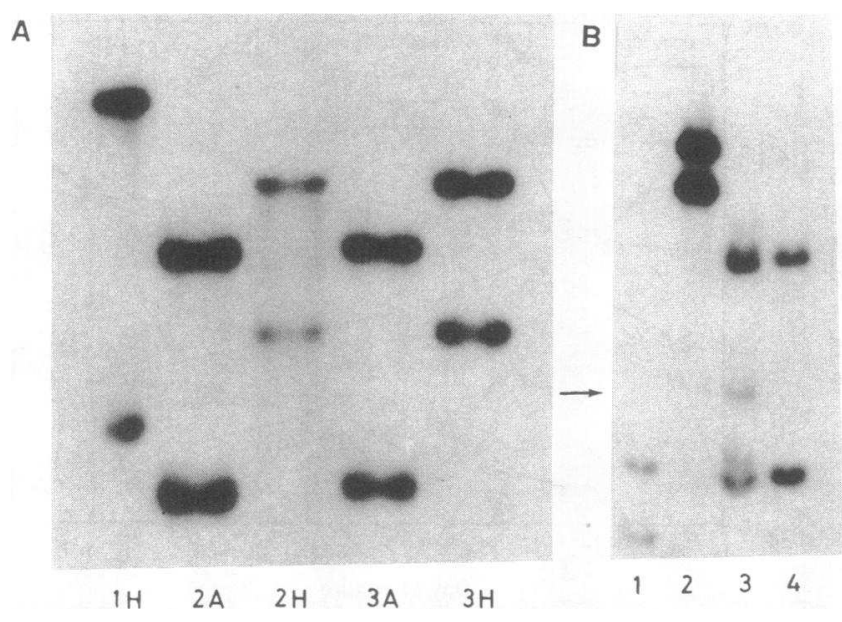

Figure 4. Autoradiographs of Southern blots of genomic DNA probed with locus-specific probes of hypervariable minisatellite sequences. $A$, DNA was digested with Alu I (lanes labeled $A$ ) or with Hinf I (lanes labeled $H$ ) and probed with p $\lambda$ MS31. Lane 1 , unrelated control; lane 2, T.D. B cell line (EBV-transformed from 5/87 marrow sample); lane 3, T.D. T cells (cultured from 4/88 blood sample, uncloned; Table I). B, DNA was digested with Hinf I and probed with p $\lambda \mathrm{g} 3$. Lane 1 , parent of T.D. (GM 2608 B cell line); lane 2, unrelated control; lane 3, T.D. B cells; lane 4, T.D. T cells. The weak band in lane 3 (arrow) is due to incomplete digestion.

allele, and $\mathrm{G}^{727} \rightarrow \mathrm{A}$ (exon 7) changing $\mathrm{Arg}_{211}$ to His in the other. We tested for these mutations by hybridizing radiolabeled ASO to DNA spanning basepairs 219-846, which was amplified from first strand ADA cDNA prepared from T.D. T cell clones $1 \mathrm{~F} 12\left(\mathrm{ADA}^{+}\right)$and $4 \mathrm{~F} 11\left(\mathrm{ADA}^{-}\right)$(see Table I).

Uncloned, amplified cDNA from T.D. T cells gave positive signals under stringent conditions with both wild-type and mutant ASO at both mutation sites; amplified cDNA from normal T cells reacted only with the wild-type ASO (Fig. $5 A$ ). The amplified ADA cDNAs were subcloned and analyzed with ASO to determine the phase of wild-type (wt) and mutant (mut) sequences on individual alleles. Of seven cloned cDNAs from $1 F 12$ cells $\left(\mathrm{ADA}^{+}\right)$, two showed an exon $4^{\mathrm{mut}} /$ exon $7^{\mathrm{wt}}$ pattern and five an exon $4^{\text {wt }} /$ exon $7^{\text {mut }}$ pattern (Fig. $5 \mathrm{~B}$ ); similarly, with $4 \mathrm{~F} 11$ cells $\left(\mathrm{ADA}^{-}\right) 4$ of 11 cloned cDNAs showed the former and 7 the latter pattern (Fig. $5 \mathrm{C}$ ). None of the subcloned cDNAs from either $\mathrm{T}$ cell clone showed a double mutant pattern or the double wild-type pattern of control $T$ cells. Levels of total ADA mRNA were similar in $\mathrm{ADA}^{+} \mathrm{T}$ cells (clone 1F12) and $\mathrm{ADA}^{-} \mathrm{B}$ cells from T.D., as were levels of mRNA for $S$-adenosylhomocysteine hydrolase (Fig. $5 \mathrm{D}$ ). The latter was used as an internal control because its gene, like that for ADA, is located on the long arm of chromosome 20 $(46,47)$.

\section{Discussion}

The finding of ADA activity in the normal range in $T$ cells cultured from patient T.D. is inconsistent with the severity of her immunodeficiency and metabolic abnormalities, which are virtually pathognomonic for complete ADA deficiency. Red cells, monocytes, granulocytes, marrow hematopoietic precursors, B cells, and B cell lines from T.D., as well as cultured $T$ cells from five other ADA-deficient SCID patients, 

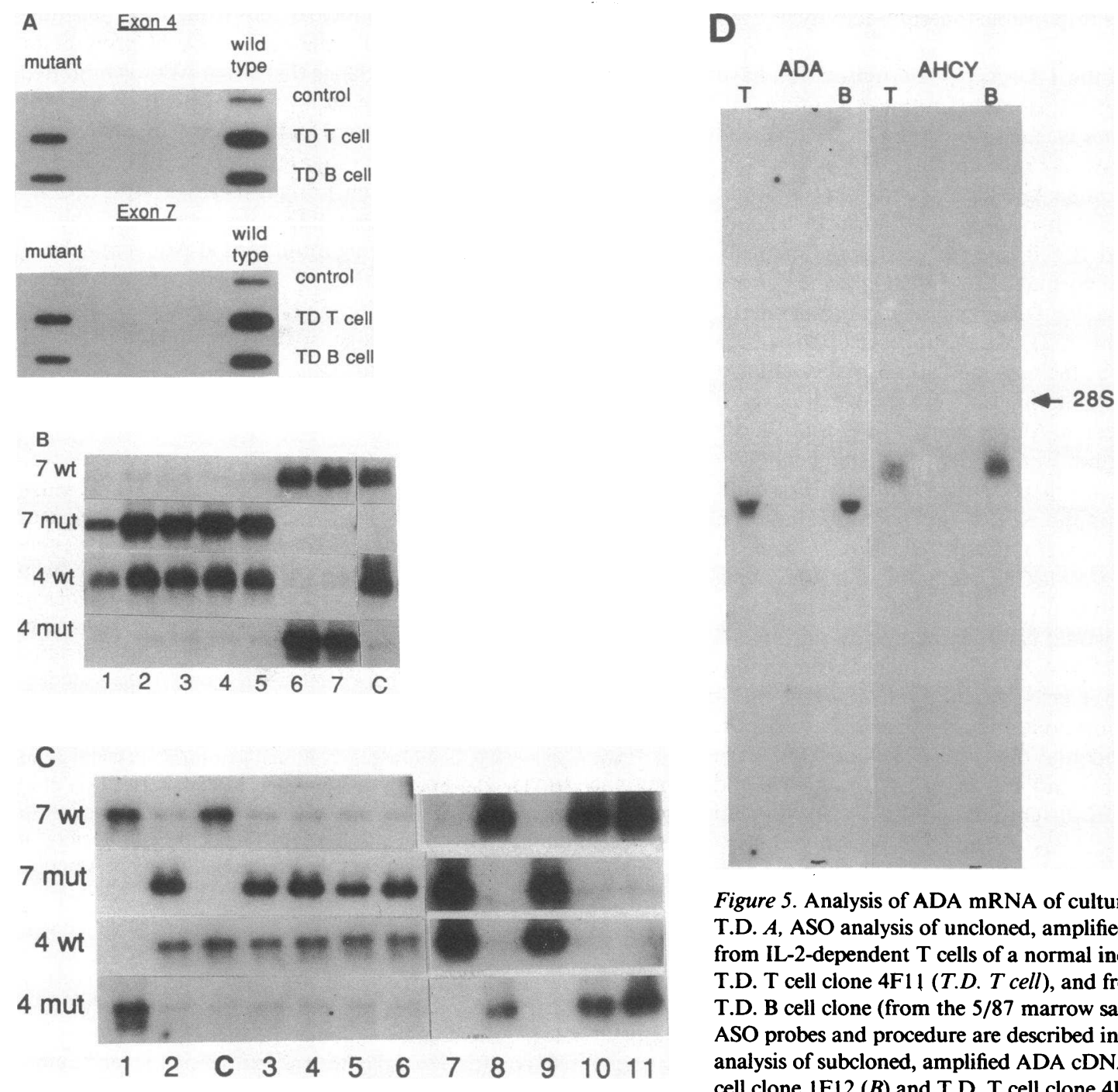

Figure 5. Analysis of ADA mRNA of cultured T and B cells from T.D. $A$, ASO analysis of uncloned, amplified ADA cDNA prepared from IL-2-dependent $T$ cells of a normal individual (control) and the T.D. T cell clone 4F11 (T.D. T cell), and from an EBV transformed T.D. B cell clone (from the $5 / 87$ marrow sample) (T.D. B cell). The ASO probes and procedure are described in Methods. $B$ and $C$, ASO analysis of subcloned, amplified ADA cDNA prepared from T.D. T cell clone $1 \mathrm{~F} 12(B)$ and T.D. T cell clone $4 \mathrm{~F} 11(C)$. $C$ indicates an identically prepared, amplified, cloned DNA sample from $\mathrm{T}$ cells of a normal control individual. $D$, Northern analysis of RNA from cultured T.D. T cells $(T)$ (from $1 / 88$ blood sample), and from an EBV-transformed T.D. B cell line (B) (from 5/87 marrow sample). The blot was first probed with a ${ }^{32}$ P-labeled fragment spanning basepairs 219-846 of ADA mRNA (see Methods) amplified by PCR from pADA211 (37), then stripped and reprobed with labeled pDEC16-1 (38) to detect $S$-adenosylhomocysteine hydrolase mRNA.

had, as expected, $\sim 1 \%$ or less of normal ADA activity. We have considered two trivial explanations for this cell- and patient-specific phenomenon. Comparison of polymorphic DNA loci, showing that $\mathrm{ADA}^{+} \mathrm{T}$ and $\mathrm{ADA}^{-} \mathrm{B}$ cells from T.D. have the same genotype, and analysis of HLA phenotype both indicate that T.D. is not a chimera; i.e., her $T$ cells were not engrafted from a donor of thymic epithelium or transfused irradiated blood. Nor does T.D. appear to be a genetic mosaic, with $\mathrm{T}$ cells possessing a functional ADA allele not present in other somatic cells. Such an allele might be generated by reversion, by a compensatory second site mutation, or by a recombination or gene conversion mechanism involving the $\sim$ 3,600 nucleotides that separate the mutations in exons 4 and 7 previously found in the T.D.-derived B cell line GM 2606 (18). Though not excluded directly, these site-specific, T cell-restricted events should be exceedingly rare. Moreover, we found that subcloned mRNAs from cloned $\mathrm{ADA}^{+}$T.D. T cells carry the same two ADA mutations found in GM 2606.

Besides lacking ADA activity $(6,10,13$, and present stud- ies), GM 2606 cells have been found to express normal or three- to fourfold increased levels of $\operatorname{ADA} \operatorname{mRNA}(37,48,49)$, but barely detectable ADA protein, estimated at $\sim 10 \%(13)$ and $0.35 \%$ (10) of normal. GM 2606 mRNA could be translated in vitro into normal-sized ADA protein (50), but when introduced into fibroblasts cDNAs containing each of the GM 2606 ADA mutations $\left(\operatorname{Arg}_{101} \rightarrow \operatorname{Trp}, \operatorname{Arg}_{211} \rightarrow\right.$ His) induced a 15-25-fold increase in ADA mRNA but no increase in ADA activity, while wild-type cDNA induced a 25 -fold increase in ADA activity (18). These results amply support the conclusion that in ADA-deficient tissues of T.D. each mutant ADA allele encodes a structurally altered, labile, and possibly nonfunctional protein. Nevertheless, our present findings raise the possibility that in her IL-2-dependent T cells, one of these mutant alleles can be expressed as catalytically active ADA with a normal $K_{\mathrm{m}}$ and heat stability. The $\mathrm{Arg}_{211} \rightarrow$ His mutation is also present in one ADA allele of the siblings D.D. and L.D. (17), whose cultured $T$ cells did not express significant ADA activity (Fig. 1; Table III). Since ADA is a monomer, it seems 
unlikely that this allele is responsible for ADA activity in T.D. T cells.

Other occurrences of the T.D. Arg $\sin _{101} \rightarrow$ Trp mutation have not been reported, but an $\mathrm{Arg}_{101} \rightarrow$ Gln mutation was found in each of four cDNA clones isolated from the GM 1715 B cell line (14), reported to have $\sim 1 \%$ of normal ADA activity (6). GM 1715 was derived from D.A., a patient with relatively mild immunodeficiency $(51,52)$. It is intriguing that ADA activity in another D.A.-derived B cell line reverted spontaneously from $\sim 8 \%$ of normal to normal; the residual enzyme of both low and high ADA expressing D.A. B cells had normal kinetic constants and heat stability (52). A D.A. fibroblast line had 3\% of normal ADA levels but the enzyme had normal calculated specific activity (53). In reviewing our records, we discovered that in 1986 we found normal ADA activity $(2,512 \mathrm{nmol} / \mathrm{h}$ per $\mathrm{mg}$ protein) in a B cell line from patient DA, independently established by Dr. M. L. Markert, Duke University (Durham, NC) (Hershfield, M. S., unpublished observations). It has been speculated that a second, as yet uncharacterized ADA allele in D.A. cells may possess a cis-acting mutation in a noncoding region, which prevents its expression as mRNA; reversion, or activation of this allele would cause expression of an mRNA encoding wild type ADA $(14,52)$. This mechanism cannot explain ADA activity in T cells of T.D. both of whose ADA alleles contain coding mutations and are expressed as mRNA.

It may not be coincidental that both T.D. and D.A. have mutations that alter $\operatorname{Arg}_{101}$ and also manifest paradoxical and variable ADA expression in lymphoid cells. An amino acid replacement might cause ADA deficiency by directly altering the active site, by preventing proper folding of the nascent peptide, or by severely diminishing stability. Such effects are likely to be intrinsic molecular properties and are unlikely to be reversed in a cell-specific manner to yield active enzyme. We postulate instead that mutations at $\mathrm{Arg}_{101}$ might increase the susceptibility of ADA to degradation in a cell-dependent manner, but do not affect the inherent enzyme activity or stability (as indicated by kinetic constants and heat stability). This hypothesis is based in part on the finding by Daddona (54) that three- to sixfold faster rates of ADA degradation in human $B$ than $T$ cell lines largely accounted for 7-12-fold higher levels of ADA activity in the T cells, suggesting that $B$ cells might have higher levels of an ADA-degrading protease than $\mathrm{T}$ cells.

We speculate that $\mathrm{Arg}_{101}$ is at the site recognized by a protease that degrades ADA, and that the protease is more active against ADA molecules in which this residue is mutated. Molecules bearing hydrophobic Trp at residue $101 \mathrm{might}$ be more susceptible to degradation than those with polar, though uncharged Gln, possibly accounting for the more severe ADA deficiency of T.D. than D.A. To account for the selective expression of ADA in cultured T cells of T.D., and by some B cell lines of D.A., we suggest that this protease might be expressed constitutively in most cells, but is under negative control by IL-2 in T cells and is expressed variably in B cells depending on state of differentiation. The postulated protease need not be specific for ADA; its downregulation might contribute to pleiomorphic changes in $\mathrm{T}$ or $\mathrm{B}$ cell physiology during activation by antigen. This hypothesis and others that might also explain the present observations should be amenable to testing in vitro.

Despite the ability of her $\mathrm{T}$ cells to express high levels of ADA activity in vitro, we have seen no evidence of ADA ex- pression in circulating mononuclear cells from T.D. This may reflect a limited ability of $T$ cells from T.D. to produce or respond to IL-2. There is evidence that when ADA is inhibited deoxyadenosine blocks expression of IL-2 and IL-2 receptor (55), and that lymphocytes of ADA-deficient patients may be defective in IL-2 production (56). Treatment with IL-2 (with continued enzyme replacement) might increase ADA activity in circulating $T$ cells of patient T.D. Further study of the expression of ADA alleles bearing mutations at $\mathrm{Arg}_{101}$ may be of value in defining the regulation of ADA activity in lymphocytes, and may help in developing rational treatment of ADA deficiency based on knowledge of the specific mutations responsible for enzyme deficiency.

\section{Acknowledgments}

Christine Hatem, Lyn Nycum, Alison Brown, and Steve Jeremiah provided expert technical assistance. We appreciate helpful discussions with Rochelle Hirschhorn, who informed us that GM 2606 was derived from patient T.D., and with Ann Akeson and John Hutton, who made available the results of their studies of the point mutations in GM 2606 before publication. We are extremely grateful to T.D. and to her physicians, Dr. Ai-Lan and Dr. Roger Kobayashi, for providing blood and bone marrow samples used in the course of these studies. We are also grateful to Drs. A. Rubenstein, R. Buckley, and R. Sorensen for blood samples from ADA-deficient patients.

This research was supported by National Institutes of Health grant DK-20902 (to Dr. Hershfield); Dr. Kurtzberg was supported by a Basil O'Connor Starter Research grant from the March of Dimes Birth Defects Foundation and is a Scholar of the Leukemia Society of America. Dr. Chaffee is a Fellow of the Leukemia Society of America.

\section{References}

1. Giblett, E. R., J. E. Anderson, F. Cohen, B. Pollara, and H. J. Meuwissen. 1972. Adenosine deaminase deficiency in two patients with severely impaired cellular immunity. Lancet. ii:1067-1069.

2. Hirschhorn, R. 1986. Inherited enzyme deficiencies and immunodeficiency: adenosine deaminase (ADA) and purine nucleoside phosphorylase (PNP) deficiencies. Clin. Immunol. Immunopathol. 40:157-165.

3. Kredich, N. M., and M. S. Hershfield. 1989. Immunodeficiency diseases caused by adenosine deaminase deficiency and purine nucleoside phosphorylase deficiency. In The Metabolic Basis of Inherited Disease. C. R. Scriver, A. L. Beaudet, W. S. Sly, and D. Valle, editors. 6th ed. McGraw-Hill Inc., New York, 1045-1075.

4. Jenkins, T. 1973. Red-blood-cell adenosine deaminase deficiency in a "healthy" Kung individual. Lancet. 2:736.

5. Jenkins, T., A. R. Rabson, G. T. Nurse, and A. B. Lane. 1976. Deficiency of adenosine deaminase not associated with severe combined immunodeficiency. J. Pediatr. 89:732-736.

6. Hirschhorn, R., V. Roegner, T. Jenkins, C. Seaman, S. Piomelli, and W. Borkowsky. 1979. Erythrocyte adenosine deaminase deficiency without immunodeficiency. Evidence for an unstable mutant enzyme. J. Clin. Invest. 64:1130-1139.

7. Perignon, J. L., M. Hamet, P. Cartier, and C. Griscelli. 1979. Complete adenosine deaminase (ADA) deficiency without immunodeficiency and primary hyperoxaluria in a 12-year-old boy. Adv. Exp. Med. Biol. 122:403-408.

8. Borkowsky, W., A. A. Gershon, L. Shenkman, and R. Hirschhorn. 1980. Adenosine deaminase deficiency without immunodeficiency: clinical and metabolic studies. Pediatr. Res. 14:885-889.

9. Hirschhorn, R., F. Martiniuk, V. Roegner-Maniscalco, A. Ellenbogen, J. L. Perignon, and T. Jenkins. 1983. Genetic heterogeneity in partial adenosine deaminase deficiency. J. Clin. Invest. 71:18871892. 
10. Daddona, P. E., B. S. Mitchell, H. J. Meuwissen, B. L. Davidson, J. M. Wilson, and C. A. Koller. 1983. Adenosine deaminase deficiency with normal immune function. J. Clin. Invest. 72:483-492.

11. Schmalsteig, F. C., G. C. Mills, H. Tsuda, and A. S. Goldman. 1983. Severe combined immunodeficiency in a child with a healthy adenosine deaminase deficient mother. Pediatr. Res. 17:935-940.

12. Hirschhorn, R., and A. Ellenbogen. 1986. Genetic heterogeneity in adenosine deaminase (ADA) deficiency: five different mutations in five new patients with partial ADA deficiency. Am. J. Hum. Genet. 38:13-25.

13. Wiginton, D. A., and J. J. Hutton. 1982. Immunoreactive protein in adenosine deaminase deficient human lymphoblast cell lines. J. Biol. Chem. 257:3211-3217.

14. Bonthron, D. T., A. F. Markham, D. Ginsburg, and S. H. Orkin. 1985. Identification of a point mutation in the adenosine deaminase gene responsible for immunodeficiency. J. Clin. Invest. 76:894897.

15. Valerio, D., B. M. M. Dekker, M. G. C. Duyvesteyn, L. van der Voorn, Th. M. Berkvens, H. van Ormondt, and A. J. van der Eb. 1986. One adenosine deaminase allele in a patient with severe combined immunodeficiency contains a point mutation abolishing enzyme activity. EMBO (Eur. Mol. Biol. Organ.) J. 5:113-119.

16. Berkvens, Th. M., E. J. A. Gerritsen, M. Oldenberg, C. Breukel, J. Th. Wijnen, H. van Ormondt, J. M. Vossen, A. J. van der Eb, and P. Meera Khan. 1987. Severe combined immunodeficiency due to a homozygous 3.2-kb deletion spanning the promoter and first exon of the adenosine deaminase gene. Nucleic Acids Res. 15:9365-9378.

17. Akeson, A. L., D. A. Wiginton, J. C. States, C. M. Perme, M. R. Dusing, and J. J. Hutton. 1987. Mutations in the human adenosine deaminase gene that affect protein structure and RNA splicing. Proc. Natl. Acad. Sci. USA. 84:5947-5951.

18. Akeson, A. L., D. A. Wiginton, M. R. Dusing, J. C. States, and J. J. Hutton. 1988. Mutant human adenosine deaminase alleles and their expression by transfection into fibroblasts. J. Biol. Chem. 263:16291-16296.

19. Markert, M. L., J. J. Hutton, D. A. Wiginton, J. C. States, and R. E. Kaufman. 1988. Adenosine deaminase (ADA) deficiency due to deletion of the ADA gene promoter and first exon by homologous recombination between two Alu elements. J. Clin. Invest. 81:13231327.

20. Hirschhorn, R., S. Tzall, A. Ellenbogen, and S. H. Orkin. 1988. Identification of a point mutation resulting in a heat labile adenosine deaminase (ADA) in two unrelated children with partial ADA deficiency. J. Clin. Invest. 83:497-501.

21. Markert, M. L., C. Slycord, and F. E. Ward. 1989. A high proportion of ADA point mutations associated with a specific alanine-to-valine substitution. Am. J. Hum. Genet. 45:354-361.

22. Messner, H. A., C. A. Izaguirre, and N. Jamal. 1981. Identification of $\mathrm{T}$ lymphocytes in human mixed hematopoietic colonies. Blood. 58:402-405.

23. Hakoda, M., M. Akiyama, S. Kyoizumi, K. Kobuke, A. A. Awa, and M. Yamakido. 1988. Measurement of in vivo HGPRT-defcient mutant cell frequency using a modified method for cloning human peripheral blood T-lymphocytes. Mutat. Res. 197:161-169.

24. Maniatis, T., E. F. Fritsch, and J. Sambrook. 1982. Molecular Cloning: A Laboratory Manual. Cold Spring Harbor Laboratory, Cold Spring Harbor, NY. 545 pp.

25. Snyder, F. F., J. Mendelsohn, and J. E. Seegmiller. 1976. Adenosine metabolism in phytohemagglutinin-stimulated human lymphocytes. J. Clin. Invest. 58:654-666.

26. Fox, I. H., C. M. Andres, E. W. Gelfand, and D. Biggar. 1977. Purine nucleoside phosphorylase deficiency: altered kinetic properties of a mutant enzyme. Science (Wash. DC). 197:1084-1086.

27. Spencer, N., D. A. Hopkinson, and H. Harris. 1968. Adenosine deaminase polymorphism in man. Ann. Hum. Genet. 32:9-14.

28. Lowry, O. H., N. J. Rosebrough, A. L. Farr, and R. J. Randall. 1951. Protein measurement with the Folin phenol reagent. J. Biol. Chem. 193:265-275.
29. Kurtzberg, J., S. H. Bigner, and M. S. Hershfield. 1985. Establishment of the DU.528 human lymphohematopoietic stem cell line. $J$. Exp. Med. 162:1561-1578.

30. Kurtzberg, J., T. A. Waldmann, M. P. Davey, S. H. Bigner, J. O. Moore, M. S. Hershfield, and B. F. Haynes. 1989. CD7+, CD4-, CD8- acute leukemia. A syndrome of malignant pluripotent lymphohematopoietic cells. Blood. 73:381-390.

31. Denning, S. M., J. Kurtzberg, P. T. Le, D. T. Tuck, K. H. Singer, and B. F. Haynes. 1988. Human thymic epithelial cells directly induce activation of autologous immature thymocytes. Proc. Natl. Acad. Sci. USA. 85:3125-3129.

32. Amos, D. B., P. Pool, and J. Grier. 1980. HLA-A, HLA-B, HLA-C and HLA-DR. In Manual of Clinical Immunology. N. R. Rose and H. Friedman, editors. American Society of Microbiology, Washington, DC. 978-986.

33. Doherty, P. J., M. Huesca-Contreras, H. M. Dosch, and S. Pan. 1989. Rapid amplification of complementary DNA from small amounts of unfractionated RNA. Anal. Biochem. 177:7-10.

34. Badley, J. E., G. A. Bishop, T. St. John, and J. A. Frelinger. 1988. A simple, rapid method for the purification of poly $A^{+}$RNA. Biotechniques. 6:114-116.

35. Belts, G. A., K. A. Jacobs, T. H. Eickbush, P. T. Cherbas, and F. C. Kafatos. 1983. Isolation of multigene families and determination of homologies by filter hybridization. Methods Enzymol. 100:266285.

36. Angelini, G., C. Preval, J. Gorski, and B. Mach. 1986. High resolution of the human HLA-DR polymorphism by hybridization with sequence-specific oligonucleotide probes. Proc. Natl. Acad. Sci. USA. 83:4489-4493.

37. Wiginton, D. A., G. S. Adrian, D. Friedman, D. Parker-Suttle, and J. J. Hutton. 1983. Cloning of cDNA sequences of human adenosine deaminase. Proc. Natl. Acad. Sci. USA. 80:7481-7485.

38. Coulter-Karis, D. E., and M. S. Hershfield. 1989. Sequence of full length cDNA for human S-adenosylhomocysteine hydrolase. Ann. Hum. Genet. 53:169-175.

39. Wong, Z., V. Wilson, I: Patel, S. Povey, and A. J. Jeffreys. 1987. Characterization of a panel of highly variable minisatellites cloned from human DNA. Ann. Hum. Genet. 51:269-288.

40. Cohen, A., R. Hirschhorn, S. D. Horowitz, A. Rubinstein, S. H. Polmar, R. Hong, and D. W. Martin, Jr. 1978. Deoxyadenosine triphosphate as a potentially toxic metabolite in adenosine deaminase deficiency. Proc. Natl. Acad. Sci. USA. 75:472-476.

41. Hershfield, M. S., R. H. Buckley, M. L. Greenberg, A. L. Melton, R. Schiff, C. Hatem, J. Kurtzberg, M. L. Markert, R. H. Kobayashi, A. L. Kobayashi, and A. Abuchowski. 1987. Treatment of adenosine deaminase deficiency with polyethylene glycol-modified adenosine deaminase. $N$. Engl. J. Med. 316:589-596.

42. Markert, M. L., M. S. Hershfield, R. I. Schiff, and R. H. Buckley. 1987. Adenosine deaminase and purine nucleoside phosphorylase deficiencies: evaluation of therapeutic interventions in 8 patients. $J$. Clin. Immunol. 7:389-399.

43. Rubinstein, A., R. Hirschhorn, M. Sicklick, and R. A. Murphy. 1979. In vivo and in vitro effects of thymosin and adenosine deaminase on adenosine deaminase deficient lymphocytes. N. Engl. J. Med. 300:387-392.

44. Daddona, P. E., and W. N. Kelley. 1981. Characterization of an aminohydrolase distinct from adenosine deaminase in cultured human lymphocytes. Biochim. Biophys. Acta. 658:280-290.

45. Schrader, W. P., B. Pollara, and H. J. Meuwissen. 1978. Characterization of the residual adenosine deaminating activity in the spleen of a patient with combined immunodeficiency and adenosine deaminase deficiency. Proc. Natl. Acad. Sci. USA. 75:446-450.

46. Hershfield, M. S., and U. Francke. 1982. The human genes for S-adenosylhomocysteine hydrolase and adenosine deaminase are syntenic on chromosome 20. Science (Wash. DC). 216:739-742.

47. Mohandas, T., R. S. Sparkes, E. J. Suh, and M. S. Hershfield. 1984. Regional localization of the human genes for S-adenosylhomo- 
cysteine hydrolase (cenq $\rightarrow 131)$ and adenosine deaminase (q131 $\rightarrow$ qter) on chromosome 20. Hum. Genet. 66:292-295.

48. Daddona, P. E., D. S. Shewach, W. N. Kelley, P. Argos, A. F. Markham, and S. H. Orkin. 1984. Human adenosine deaminase: cDNA and complete primary amino acid sequence. J. Biol. Chem. 259:12101-12106.

49. Adrian, G. S., D. A. Wiginton, and J. J. Hutton. 1984. Characterization of normal and mutant adenosine deaminase messenger RNAs by translation and hybridization to a CDNA probe. Hum. Genet. 68:169-172.

50. Adrian, G. S., and J. J. Hutton. 1983. Adenosine deaminase messenger RNAs in lymphoblast cell lines derived from leukemic patients and patients with hereditary adenosine deaminase deficiency. $J$. Clin. Invest. 71:1649-1660.

51. Uberti, J., J. J. Lightbody, J. W. Wolf, J. A. Anderson, R. H. Reid, and R. M. Johnson. 1978. The effect of adenosine on mitogenesis of ADA-deficient lymphocytes. Clin. Immunol. Immunopathol. 10:446-458.

52. Uberti, J., W. D. Peterson, Jr., J. J. Lightbody, and R. M. Johnson. 1983. A phenotypically normal revertant of an adenosine deaminase-deficient lymphoblast cell line. J. Immunol. 130:28662870.

53. Daddona, P. E., M. A. Frohman, and W. N. Kelley. 1980. Human adenosine deaminase and its binding protein in normal and adenosine deaminase deficient fibroblast cell strains. J. Biol. Chem. 255:5681-5687.

54. Daddona, P. E. 1981. Human adenosine deaminase: properties and turnover in cultured $\mathrm{T}$ and B lymphoblasts. J. Biol. Chem. 256:12496-12501.

55. Ruers, T. J. M., W. A. Buurman, and C. J. van der Linden. 1987. 2 -Deoxycoformycin and deoxyadenosine affect IL 2 production and IL 2 receptor expression of human T cells. J. Immunol. 138:116122.

56. Cowan, M. J., W. Smith, and A. J. Ammann. 1989. Interleukin 2 responsive lymphocytes in patients with adenosine deaminase deficiency. Clin. Immunol. Immunopathol. 53:59-67.

57. Levy, Y., M. S. Hershfield, C. Fernandez-Mejia, S. H. Polmar, D. Scudiery, M. Berger, and R. U. Sorensen. 1988. Adenosine deaminase deficiency with late onset of recurrent infections: results of treatment with polyethylene glycol-modified adenosine deaminase (PEGADA). J. Pediatr. 113:312-317. 